University of Wollongong

Research Online

University of Wollongong in Dubai - Papers

University of Wollongong in Dubai

$1-1-2017$

\title{
From Islamic Dress and Islamic Fashion to Cool Islam: An Exploration of Muslim Youth Hybrid Identities in the West
}

Imene Ajala

University of Wollongong in Dubai, imene@uow.edu.au

Follow this and additional works at: https://ro.uow.edu.au/dubaipapers

\section{Recommended Citation}

Ajala, Imene: From Islamic Dress and Islamic Fashion to Cool Islam: An Exploration of Muslim Youth Hybrid Identities in the West 2017, 1-11.

https://ro.uow.edu.au/dubaipapers/907

Research Online is the open access institutional repository for the University of Wollongong. For further information contact the UOW Library: research-pubs@uow.edu.au 
The International Journal of

Interdisciplinary

Cultural Studies

From Islamic Dress and

Islamic Fashion to Cool Islam

An Exploration of Muslim Youth

Hybrid Identities in the West

IMENE AJALA

(1) COM MON

(7) GROUN 


\section{EDITOR}

Gerassimos Kouzelis, University of Athens, Greece

HEAD OF JOURNAL PRODUCTION

McCall Macomber, Common Ground Research Networks, USA

\section{EDITORIAL ASSISTANT}

Hannah Werner, Common Ground Research Networks, USA

\section{ADVISORY BOARD}

The Interdisciplinary Social Sciences Research Network recognizes the contribution of many in the evolution of the Research Network. The principal role of the Advisory Board has been, and is, to drive the overall intellectual direction of the Research Network. A full list of members can be found at $\mathrm{http}: / /$ thesocialsciences.com/about/advisory-board.

\section{PEER REVIEW}

Articles published in The International Journal of Interdisciplinary Cultural Studies are peer reviewed by scholars who are active participants of the Interdisciplinary Social Sciences Research Network or a thematically related Research Network. Reviewers are acknowledged in the corresponding volume of the journal. For a full list of past and current Reviewers, please visit http://thesocialsciences.com/journals/editors.

\section{THE INTERNATIONAL JOURNAL OF INTERDISCIPLINARY CULTURAL STUDIES http://thesocial sciences.com \\ ISSN: 2327-008X (Print) \\ ISSN: 2327-2554 (Online) \\ http://doi.org/10.18848/2327-008X/CGP (Journal)}

First published by Common Ground Research Networks in 2017 University of Illinois Research Park

2001 South First Street, Suite 202

Champaign, IL 61820 USA

$\mathrm{Ph}:+1-217-328-0405$

http://cgnetworks.org

The International Journal of Interdisciplinary

Cultural Studies is a peer-reviewed, scholarly journal.

\section{COPYRIGHT}

(C) 2017 (individual papers), the author(s)

(C) 2017 (selection and editorial matter),

Common Ground Research Networks

\section{(ㅇ)(1) $(5)$}

Some Rights Reserved.

Public Licensed Material: Available under the terms and conditions of the Creative Commons Attribution-NonCommercial-NoDerivatives 4.0 International Public License (CC BY-NC-ND 4.0). The use of this material is permitted for non-commercial use provided the creator(s) and publisher receive attribution. No derivatives of this version are permitted. Official terms of this public license apply as indicated here: https://creativecommons.org/licenses/by-nc-nd/4.0/legalcode

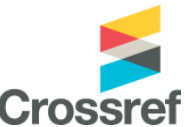

Common Ground Research Networks, a member of Crossref

\section{ARTICLE SUBMISSION}

The International Journal of Interdisciplinary Cultural Studies publishes quarterly (March, June, September, December). To find out more about the submission process, please visit http://thesocialsciences.com/journals/call-for-papers.

\section{ABSTRACTING AND INDEXING}

For a full list of databases in which this journal is indexed, please visit http://thesocialsciences.com/journals/collection.

\section{RESEARCH NETWORK MEMBERSHIP}

Authors in The International Journal of Interdisciplinary Cultural Studies are members of the Interdisciplinary Social Sciences Research Network or a thematically related Research Network. Members receive access to journal content. To find out more, visit http://thesocialsciences.com/about/become-a-member.

\section{SUBSCRIPTIONS}

The International Journal of Interdisciplinary Cultural Studies is available in electronic and print formats. Subscribe to gain access to content from the current year and the entire backlist. Contact us at support@cgnetworks.org.

\section{ORDERING}

Single articles and issues are available from the journal bookstore at http://cgscholar.com/bookstore.

\section{HYBRID OPEN ACCESS}

The International Journal of Interdisciplinary Cultural Studies is Hybrid Open Access, meaning authors can choose to make their articles open access. This allows their work to reach an even wider audience, broadening the dissemination of their research. To find out more, please visit http://thesocialsciences.com/journals/hybrid-open-access.

\section{DISCLAIMER}

The authors, editors, and publisher will not accept any legal responsibility for any errors or omissions that may have been made in this publication. The publisher makes no warranty, express or implied, with respect to the material contained herein. 


\title{
From Islamic Dress and Islamic Fashion to Cool Islam: An Exploration of Muslim Youth Hybrid Identities in the West
}

\author{
Imene Ajala, ${ }^{1}$ University of Wollongong in Dubai, United Arab Emirates
}

\begin{abstract}
Debates regarding visible Islamic practices in the West and particularly in European secular spaces reflect the tensions related to religious expression in the public sphere. Assumptions are often being made on the meaning of these practices leading to speculations on the willingness of young Muslims to be fully part of society at large. However, Islam and its practices are not immune to global cultural, individualist, consumerist, and neoliberal trends. This paper thus explores the new dynamics characterizing Islamic dress so as to reveal that far from separating themselves from society at large, young Muslims in the West adopt Islamic forms of Islamic dress that are reinterpreted in light of these consumerists, cultural, and neoliberal trends. Therefore, young Muslims do not showcase a closed identity but on the contrary, display different layers of identity translated into hybrid dressing practices. The paper focuses on two case studies of hybrid expressions: modest fashion and Muslim streetwear.
\end{abstract}

Keywords: Islam, Youth, Identity, Modest Fashion, Hybridity, Consumerism

\section{Introduction}

I $\mathrm{n}$ a European context marked by the heavy securitization of Islam and increasing anxieties about Foreign Terrorist Fighters joining the so-called Islamic State and sometimes returning to Europe, Muslim youth comes under increasing scrutiny. Concerns about Muslims' societal integration often crystallize in the central question of Islamic religiosity, its practice and its underlying meaning. It is thus not surprising that veiled women, whether adopting the hijab or the niqab, are at the forefront of these tensions due to their visibility in the public space. When the hijab is perceived as a threat, the assumptions underlying its significance for non-Muslim Europeans navigate between viewing it as the symbol of oppression of women, a sign of support for Islamic extremism, an assertion of hatred for Western society or a sign of backwardness, among others. In sum, depictions made in the purest Orientalist fashion, ignoring change (Berg and Lundahl 2016). Orientalist and neo-colonial discourses reactivating binary readings further deprive Muslim women of their agency (O'Brien 2016). This is despite the fact that, since Françoise Gaspard and Farhad Khosrokhavar study in 1995 (who had already concluded that women wearing the veil desired to be both French and Muslim), a number of studies have emphasized the autonomy of women in their choice of veiling and the plurality of motives behind this choice (Gaspard and Khosrokhavar 1995; Amer 2014; Tarlo 2015). These neocolonial perspectives also essentialize Muslims as one single homogeneous block when in fact they constitute a diverse group (Warner and Wenner 2006; Laurence and Vaïsse 2006; O'Brien 2016).

This article seeks to embed the veil and other dressing practices adopted by Muslim youth in the context of Islamic fashion to reflect on global trends which also affect Islam, including the neoliberal dynamics reflected in consumerism. Taking these dynamics into account helps to deconstruct and shed light on the different layers of identity and conceptions of modernity that wearers of Islamic fashion claim through the adoption of a Muslim dress in non-Muslim societies and largely secular spaces. This article emphasizes the adoption of Islamic Fashion and Muslim Streetwear as a result of the interactions of neoliberal and postmodern globalizing trends. It does so by using voices from the Islamic fashion sphere traced through general press coverage (thus

\footnotetext{
${ }^{1}$ Corresponding Author: Imene Ajala, PO Box 20183, Department of Arts and Humanities, University of Wollongong in Dubai, Dubai, 20183, United Arab Emirates. email: AjalaImene@uowdubai.ac.ae
}

The International Journal of Interdisciplinary Cultural Studies

Volume 12, Issue 3, 2017, www.thesocialsciences.com

(C) Common Ground Research Networks, Imene Ajala, Some Rights Reserved,

(CC BY-NC-ND 4.0). Permissions: support@cgnetworks.org

ISSN: 2327-008X (Print), ISSN: 2327-2554 (Online)

https://doi.org/10.18848/2327-008X/CGP/v12i03/1-11 (Article) 
ensuring at least a form of resonance in society at large) and the messages explicitly delivered on some products of Muslim streetwear, predominantly the themes of consumerism and individualization. These voices and themes counter an essentialist view of Islam, including Islam in the West, as a homogenous sphere immune to change and to any external global dynamic. The analysis relies on the content analysis of a range of press archives in English collected through Lexis-Nexis over a period of three years (January 2014 to January 2017), an extensive set of primary and secondary sources as well as on the textual analysis of a sample of messages inscribed on Muslim Streetwear products. The article limits its scope to Muslim communities living in European societies, with a particular emphasis on France and the United Kingdom as homes to significant Muslim minorities (Hackett 2016) and as stages of heated debates, particularly in secular France.

\section{Securitization and Identity}

The terrorist threat is a predominant issue on the European security agenda, especially the problem of Foreign Terrorist Fighters and their potential return. Europol notes that:

While most terrorist attacks in the EU were carried out by separatist groups in 2014, they were generally small-scale, and have continued to decline in numbers in recent years. The main concern reported by EU Member States (EU MS) is the phenomenon of jihadists travelling to and from conflict zones, which has enhanced the capabilities and the resolve of religiously inspired terrorist individuals and groups to perpetrate terrorist acts in the EU. (Europol 2015, 7)

It is estimated that around 7,000 European Muslims have hit the road to Syria and Iraq (Centre for the Analysis on Terrorism 2016). The domination of this issue on the political agenda and the activation of counter-terrorist measures have exacerbated the tensions and debates related to the integration of Muslim minorities in Europe, including visible practices of religiosity. The global securitization context has profoundly impacted the perceptions and rhetoric used about the integration of Muslims in Europe, and more generally in the West, exacerbating the tensions due to the encounter between religious practices and deeply secularized spaces (Césari 2009; Césari 2013; Silvestri 2007a; Ajala 2014). Muslims in the West do not only constitute a political but also a cultural threat for many in Europe, the core issue here being identity (Savage 2004). The quite spectacular debate over the "burkini" (a beach wear for women designed to fulfill the requirements of the Muslim dress code) which agitated France in summer 2016 was only one of the multiple controversies occasionally emerging about Islam in the public sphere. The controversy, happening after the bloody attacks of July 14 in Nice, perfectly illustrates the culmination of tensions arising from the securitization of Islam. The local authorities issuing the ban on the burkini from the beach, before its cancellation by the Conseil d'Etat, thus articulated the argument of threat to public order in their decision (Berg and Lundah 2016). Following this line of reasoning, signs of religious visibility such as the veil or the burkini become thus equated, cognitively, along with the same continuum as terrorism (Blanc, Loisel, and Sherrer 2005: Berg and Lundahl 2016). In parallel, 55 percent of Europeans wish to suspend the entry of Muslim immigrants into Europe (Goodwin, Raines, and Cutts 2017). As noted by Samad and Sen: "there has been a blurring of the distinction between political activity, community networks, immigration issues, and organized violence. Muslim communities are treated as dangerous, and their networks are under suspicion for having links to terrorism," which leads to increasing securitization (Modood, Triandafyllidou, and ZapataBarrero 2006, 3). Coming back to the issue of clothing, non-Muslim, general European populations consequently think that removing public signs of religiosity is necessary for integration (Gallup 2009).

These strong rejections "otherizing" Muslims as non-Western (Berg and Lundah 2016) appear to be rooted in the assumption that religious and national identities are incompatible. More 
specifically, Muslim identity and its assumed corollary, allegiance to the global community of Muslim believers or the "umma," would conflict with allegiance to the nation. The terrorist attacks committed by holders of European passports that took place in France in 2015 and Brussels in 2016 seem to have increased suspicions of disloyalty. The question of self-identification constitutes, in fact, a crucial issue regarding divided loyalties and the articulation of religion and citizenship as complementary or on the contrary, competing concepts (Hussain and Bagguley 2005; Mogahed 2007). While European non-Muslim populations identify as national citizens before members of their faith, European Muslims tend to identify first as Muslims and then according to their citizenship (Pew Global Attitudes Project 2006). General populations in Spain, Germany, Great Britain and France all identify first with their nationality rather than with their religion (Pew Global Attitudes Project 2006a, 4). On the contrary, Spanish, German, and especially British Muslims tend to identify first as Muslims rather than with their nationality. This identification is at a level similar to that in Pakistan, Nigeria, and Jordan, and at a higher level than that in Egypt, Turkey, and Indonesia (Pew Global Attitudes Project 2006). This is the case for 81 percent of British Muslims, 69 percent of Spanish Muslims, 66 percent of German Muslims and 46 percent of French Muslims (Pew Global Attitudes Project 2006).

If the problematic nexus between religion and national identity crystallizes the debate over Muslims' integration, this is also because there has been an increasing Muslim self-identification. Common experiences of societal exclusion combined with a greater visibility of Islam since the Iranian Revolution in 1979 have fuelled the feeling of belonging to a religion with legitimacy (Césari 1994; Laurence and Vaïsse 2006). Primo-migrants or the first generation of migrants tended to refer to their countries of origin as their "imagined community" to reuse Benedict Anderson's expression. On the contrary, the new generation conceives of their Muslim identity as being related to the global umma. The religious identity assignation has replaced the ethical identity assignation in the perception of the migrants and later generations (Silvestri 2007). The number of Muslims self-identifying as Muslims has increased, and in younger generations, this takes the form of a strong claim of religious identity (Dargent 2003; Laurence and Vaïsse 2006). Having said that, the upsurge of religiosity among young people takes places along a strong individualization of practices (Roy, 2004: Salvatore 2004, 1021: Césari 2009, 153) constituting the base of a specifically European Islam (Salvatore 2004, 1021). Identity is, in fact, a complex, plural, and multi-layered factor. In their study on the British Pakistani population, Hussain and Bagguley show the expression of a multi-ethnic citizenship identity where religion, in conjunction with the ethnic background, provides a sense of cultural identity. This sense of cultural identity is especially the case for younger generations who not only consider themselves as British citizens but also "members of religious, racial, ethnic and linguistic groups" (Hussain and Bagguley 2005, 414). Despite the growing religious practise, Islam is not the exclusive identity referential so that twothirds of French Muslims do not self-identify using the religious referent but using their origin, their district, their education or their family situation (Beauchemin, Hamel, and Simon 2016).

The imperative of not essentializing Muslim communities also precisely means taking into account their multiple identities. Muslims and Islam for that matter, should not be treated in isolation and as exceptional objects escaping globalization and its manifestations. Muslims' identity may be articulated by some for political activism, but that does not necessarily mean that all Muslims will do so (Silvestri 2007).

To conclude, the action of adopting a visible Islamic practice (wearing the veil) is mostly framed in this heavily securitized context, conflating Islam and terrorism, and de facto shutting down other prevalent forces in the pattern of "Global Islam." Such a frame concurs to favor an essentialist reading of any display of Muslim religiosity. We suggest to move the act of adopting the veil in a non-Muslim context into an equal but overlooked frame shaping Global Islam, relying not exclusively on political and security forces but on economic and sociological forces, which are global consumerism and growing individualization. 


\section{Political Economy of Islam and Modest Fashion}

Neo-liberal values and consumerism have affected all religions, including Islam. This trend can be verified with the increase of marketing strategies mobilizing an Islamic referent (Gauthier and Martikainen 2013; Chaambi et al. 2012).

The Pew Research Center estimates that the world Muslim population is expected to rise from 1.7 billion in 2014 to 2.2 billion by $2030(26.4 \%)$ with a median age of thirty years old (quoted in Thomson Reuters 2015). From an economic point of view, this increasing young population represents potential consumers and opportunities for business. Alia Khan, the founder of Islamic Fashion Design Council, an organisation established to develop the Islamic fashion industry in Dubai, defines Islamic fashion as clothes "worn primarily by practising Muslims who have committed to the Islamic principles of dressing," adding "a secondary following of conservative consumers ranging from people of other faiths, modest consumers" (Khaishgi 2014). Consumer spending in the sector of Islamic Fashion has reached 266 billion dollars in 2013 (Thomson Reuters $2015,8)$. The Muslim clothing market represents 11.9 percent of the global expenditure and is expected to reach 488 billion dollars by 2019 (Thomson Reuters 2015). E-commerce focused on the Muslim consumers was estimated at 4.7 billion dollars in 2013 and though it is only a small percentage of global clothing, it is the fastest growing segment (Thomson Reuters 2015). The Internet functions indeed as "a taste making mechanism, an ideological category, and a marketing device" (Lewis and Tarlo 2011, 16). The rise of Islamic fashion goes in hand in hand with the rise of a transnational, virtual sphere of modest fashion influencers, sometimes dubbed the "hijabistas" (neologism formed by the conjunction of hijab and fashionista), using the social media favored by the digital natives such as Facebook, Twitter, and Instagram. The phenomenon is also noticeable with the emergence of modest fashion photography, of Muslim Beauty Pageants, of modelling agencies, thus creating heated debates about the concept of modesty as we shall see (Thomson Reuters 2015).

Sizeable markets are not limited to the Muslim world as Muslims in Western Europe (Germany, France, UK) plus North America (US, Canada) collectively spent an estimated 22 billion dollars on clothing and footwear in 2012. This makes the western Muslim clothing market second only after Turkey. Muslims in the United States lead this grouping with an estimated 6.7 billion dollars in clothing and footwear expenditure" (Thomson Reuters 2015, 163). Four out of the ten top Muslim e-commerce markets are Western markets with Muslim consumers; the United States (second only to Turkey), Germany (fifth), the United Kingdom (sixth) and France (seventh) (Thomson Reuters 2015, 170). Western Muslims are thus major targets of the sector (Thomson Reuters, 2015, 169). Events like the Muslim Lifestyle Expo in England or the "Rassemblement du Bourget" in France function as platforms for halal-oriented consumerism.

Modest fashion can also appeal to non-Muslim consumers (Thomson Reuters 2015). There is indeed a growing demand coming not only from Muslim consumers but also other religious communities (Lewis and Tarlo 2011). Some companies have precisely embraced the term of "modest" in order not to restrict it to any religious segment (Lewis and Tarlo 2011). Aheda Zenetti, the Autralian creator of the burkini has confirmed for example that many of her clients are nonMuslims (Llana 2016). The lines separating "general" fashion from Islamic and Modest fashion may be increasingly blurry in the future, all the more general retailers are increasingly interested in this niche market. Large retailers such as DKNY and Tommy Hilfiger have designed collections for Ramadan (Arango 2016). British retailer Marks and Spencer has been offering burkinis since 2013 (Llana 2016). HandM featured a model in a headscarf in one of its ad campaigns (Friedman 2016). Japanese retailer Uniqlo collaborated with Hana Tajima, a Muslim fashion designer, to offer a special collection as well (Paton 2016). The luxury brand Dolce and Gabbana introduced a collection of abayas with matching headscarves sold in the Middle East and in select Dolce stores in London, Milan, Munich, and Paris (Friedman 2016).

The world of 'regular' fashion seems thus to step into the sphere of Islamic or modest fashion while a similar move goes the other way round: the world of Islamic or modest fashion is making 
timid incursions in the world of "regular" fashion. Indeed, the New York Fashion Week of September 2016 featured a modest fashion collection by Anniesa Hasibuan, an Indonesian designer, where every model was wearing a hijab (Paton 2016).

Such encounters can be apprehended theoretically through the postcolonial perspective on hybridity. Contemporary postcolonial theory posits indeed that hybridity permits the escape of a strictly binary pattern of reflection and creates a third space where identities are fluid and can be negotiated (Bhabha 1994). This implies an encounter experienced positively, as a revitalization, or negatively, as a threat (Prabu 2005; Werbner 2001). At the negative level, Patrick Haenni emphasizes the "foundational tension" at the core of this hybridization process, tensions which interprets trends related to modest fashion as a threat or a diversion from the Western model (Haenni 2008, 2). Such interpretations are prevalent in the reactions to the strategies of general retailers we exposed earlier. The French Minister of Families, Childhood and Women's Rights, Laurent Rossignol thus declared in March 2016 that the brands engaging in the market were "irresponsible" and promoted "the confinement of women bodies" (Dupont and Garnier 2016). She received support from some feminist associations such as the French Coordination for Women's European Lobby and from the President of the High Council for Men and Women Equality, Danielle Bousquet (Dupont and Garnier 2016). Another major French feminist figure, Elisabeth Badinter, also called for the boycott of these brands as she identifies a growing contestation of Human Rights' universalism in the name of cultural relativism and considers that the growing number of women wearing the hijab results from growing Islamist pressure (Truong 2016). On a similar level but in the United Kingdom, and as an echo to the burkini controversy, Yasmin Alibhai-Brown, a famous British Muslim writer talks about the "Islamification" of fashion, contributing to legitimising a conservative dress code that sanctions the oppression of women (Alibhai-Brown 2016).

Always at the negative level but on the Muslim side, another threat is perceived by tenants of an anti-capitalist and Marxist perspective whereby these dynamics are seen as extending market logics and attacking spirituality (Chaambi et al. 2012). However, the strongest critic is addressed on a spiritual and religious level. Indeed, the concept of modesty, which also gets reshaped and remodelled in this third space, necessarily departs from its original meaning though there has always been some latitude on the interpretation of the concept. The definition of modesty is by no means fixed (Lewis and Tarlo 2011). The Global Islamic Economy Report, citing the Quranic verses calling for modesty, asserts that "Muslim fashion is driven by an underlying Islamic mandate to preserve modesty" but also acknowledges that "there is a wide diversity in interpretation and adoption of 'modesty' among Muslims across the world (...), geographic/cultural heritage also plays a strong role," thus leaving room for diversity (Thomson Reuters 2015,162$)$. As the use of the Internet contributes to "displace discourses about modesty away from traditional religious authority structures," communities, especially women communities, reinvent what they understand as modest (Lewis and Tarlo 2011, 14). A Dubai-based designer, Ahmed Ammar explains that "Islamic fashion is drawing on more western influences" (Swan 2015). Consequently, targets of conservative groups no longer target only non-veiled women but also women considered to be veiled in an inappropriate manner (Haenni 2011). Mariah Idrissi, the model who appeared in the ad campaign for HandM explained that while she expected negative reactions from some women, the criticisms she got were from male Muslims stating that "this isn't hijab" " when she expected in fact that they would be "defending" her (Walker 2016),28). In Istanbul, one of the centres of Islamic fashion, conservative Muslims demonstrated on occasion of a fashion show to denounce what they perceived as forms of immorality (Arango 2016).

What about cases where the hybridity revitalization is experienced positively? Anniesa Hasibuan, the Indonesian designer of Modest Fashion whose designs were displayed during New York's Fashion Week, declared that hijab is "a part of a Muslim woman's identity, an identity they are asserting more confidently" (Paton 2016). Her take on Western contexts is insightful: she adds that "fashion is one of the outlets in which we can start that cultural shift in today's society to 
normalize the hijab in America and other parts of the West, so as to break down stereotypes and demystify misconceptions" (Paton 2016). Another designer, Calvin Thoo, identifies a "crisis where Islam has probably been given a bad name by extremists", and he wants to "show modest dress does not have to mean somber, or boring or so complicated" (Friedman 2014). Shelina Janmohamed, vice president of the modest fashion brand Ogilvy Noor, explains that: "The rise in modest fashion over the last decade has come hand in hand with the emergence of 'Generation M': Muslims who believe that faith and modernity go hand in hand. They want to wear their religion with pride but also feel part of the societies around them' (Paton 2016). Melanie Elturk, chief executive of an American modest fashion brand, Haute Hijab, concurs on Instagram that "fashion is one of the outlets in which we can start that cultural shift in today's society to normalise hijab in America so as to break down stereotypes and demystify misconceptions" (Asher 2016). All these voices concur towards two directions: normalizing a piece of cloth whose meaning gets distorted in the context of securitization and asserting modernity. In other words, as stated by Lewis, "alongside the depiction of Islam as a religion of peace and universal values, the depiction of Islam as part of contemporary consumer culture is an effective way to convey the message they live in the same world as everyone else" (Friedman 2014).

\section{Muslim Street Wear and Cool Islam}

Muslim or Islamic Street Wear is a style of urban clothing which takes into account Islamic prescriptions in terms of dress and occasionally conveys Islamic messages. Hybrid practises associating an Islamic referent and any cultural form of expression tied to youth, pop, or street culture in a broad sense can be identified in the emergence of "Islamic rap" and Muslim streetwear for example, consecrating a combination of pop culture and ethics (Amghar 2003; Haenni 2008). During the Danish Cartoons controversy, a German of Turkish origin, Melih Kesmen created a tshirt bearing the slogan "I love my prophet" before launching his brand of street wear, Styleislam, following the success of his design (Agnès 2011). Style Islam became an online fashion label in 2008 (Overmeyer 2013). A range of brands are present on this niche market. The French brand LSA ("Le savoir est une arme," in other words, knowledge is power) was created in 2005 by the rapper Médine. The brand dresses rappers of the Music label DIN (which happens to mean religion in Arabic) records. The website ${ }^{2}$ indicates that consumers by buying LSA products contribute to funding humanitarian projects of the association LSA ACT, such as a soccer game event organized in Gaza. Buyers are generally young Muslims, with university students constituting high shares, from Europe but also from Middle Eastern countries such as Saudi Arabi, Egypt, and The United Arab Emirates. They are typically between seventeen and thirty-five years old according to the founder of StyleIslam (GulfMercury.com 2010). Kesmen has explained how the personalization of his Tee-shirt was met with success by fellow young Muslims and how it inspired him the creation of a fashion brand, Style Islam: "It became clear to me that I wasn't the only Muslim wanting to convey a message to society in a non-verbal way with a statement on my chest-a statement that is positive and speaks for itself" (Overmeyer 2013). Message T-Shirts can enlighten us as to these messages ${ }^{3}$; some reflect the ideal ethics of Islam (Pras et Vaudour-Lagrace 2007): Haqq (meaning truth in Arabic), Hobb (Love), Tawhid (oneness of God), Sabr (enduring capacity). Visually speaking, some terms are incorporated in the form of Arabic calligraphy. Other messages refer to fundamental pillars of Islam: "Shahada" for the profession of faith, "Ramadan" for the month of fasting, "Mecca," "Al Medinah" regarding pilgrimage to Mecca, "Qibla," "Salat keeps together" or "Salat always get connected" for prayer. The individualization of religious practises transpires in the use of personal pronouns: "Hijab My Right My Choice," "Everyday I'm Muslim," "Islam my way of life," "I love my prophet," "I'm Muslim Don't panick," "Don't trust media ask

\footnotetext{
${ }^{2}$ http://din-records.com/shop-lsa/ Accessed March 10, 2017

${ }^{3}$ Seventy-three products with messages have been considered for this study. Some brands were selected in a pragmatic approach, mainly on the basis that they produce this type of product (message Tee-shirt): Style Islam, Le Savoir est une Arme, Muslimstreetwear and Ummah Gear.
} 
me about Islam." Phrases such as "Muslim by nature," "Muslim forever," "Islam my way of life," or "Everyday I'm Muslim" emphasize self-identification. "Hijab my Choice, My right, My life" is even more interesting as it appeals to an individualist rhetoric: if hijab in this sentence is replaced by any other product with the expression "my choice, my right, my life," one can perceive the general trend of increasing emphasis on the representation of the self (Gauthier and Martikainen 2013). Thus, the explanation does not refer to the idea of religious obligation but on the contrary, to the idea of a conscious and individual choice as claimed by the wearer of the Tee-shirt. Other messages seem more inscribed in a normalizing perspective, similar to what modest fashion actors convey. They aim at fighting stereotypes and confusions resulting from the securitization generated by the media: "Islam, Faith, Guidance, Devotion, Peace," "Know Islam Know Peace" or "Islam is Peace." Muslim minorities in the West thus assert, in their way of life, their religiosity in parallel with the adoption of youth and pop culture code. Modest fashion and Muslim streetwear are then direct products deriving from the global neoliberal, increasingly individualized environment leading to "the growing commodification of religious experience within modern consumer culture" (Lewis and Tarlo 2011, 16). The assertion of Muslim identity and pride of being part of Western society are claimed together: one can be Muslim and cool, a result of "Cool Islam" (Boubekeur 2005).

\section{Conclusion}

The geopolitical context of Global Islam and excessive securitization contribute to favour essentialist readings of the different forms of Muslim dress, especially female dress, despite the academic contributions in the field asserting the agency of women in articulating their personal choices. With the rise of Islamic fashion, which, under increasing contact and redefinition with non-Muslim spheres gets relabeled as modest fashion, the consideration of such dresses not only through a political and anthropological framework but through an economic framework sheds light on the "normal" aspect of Muslim dress, resulting from hybridizing practises rooted in global neoliberal and postmodern forces, namely individualization and consumerism.

This article, by reviewing the latest developments in the modest fashion sphere and the rhetoric underpinning these developments, as well as exploring concrete products of Muslim streetwear, allows at a modest level to deconstruct and make explicit the assertion of young Muslims in Europe adopting these products; the pride of not only being Muslim, but also, Western, modern and cool. Finally, it is worth noting that this assertion itself does not go unnoticed from a Muslim perspective and is rejected by conservative Muslims. All of this suggests that the fault line separating Muslims and non-Muslims in a binary manner hides the even more complex fault lines separating Muslims on these dynamics as well as non-Muslims. Inspiring territories for further research. 


\section{REFERENCES}

Adida, Claire L., David D. Laitin, and Marie-Anne Valfort. 2016. Why Muslim Integration Fails in Christian-Heritage Societies. Cambridge, MA: Harvard University Press.

Agnès, M. 2011. "Les jeunes séduits par le streetwear islamique." ["Young People Attracted by Islamic Streetwear"]. Zaman France. Accessed March 10, 2017. http://www.zamanfrance.fr/article/les-jeunes-seduits-par-le-streetwear-islamique.

Ajala, Imene. 2014. "Muslims in Europe after 9/11: Securitization, Identities and Loyalties." Journal of Muslim Minority Affairs 34 (2/3): 123-33.

Alibhai-Brow, Yasmin. 2016. "Bin the burkini! As M\&S Launches Its UK burkini, Muslim Writer Yasmin Alibhai-Brown Says This Insidious Islamification of Fashion Is a Terrible Blow for All Women." The Daily Mail, April 2. http://www.dailymail.co.uk/debate/article3519932/Bin-burkini-M-S-launches-UK-burkini-Muslim-writer-YASMIN-ALIBHAIBROWN-says-insidious-Islamification-fashion-terrible-blow-women.html.

Amer, Sahar. 2014. What is Veiling? Chapel Hill, NC: The University of North Carolina Press.

Amghar, Samir, 2003, "Rap et Islam: quand le rappeur devient imam." ["Rap and Islam: When the Rapper becomes Imam"] Hommes et Migration [Men and Migration] 137 (1243): 88-93.

Arango, Tim. 2016. “Turkey's Islamic Fashion Revolution.” The New York Times, September 17. https://www.nytimes.com/2016/09/18/world/europe/turkeys-islamic-fashion-revolution. html?_r=0.

Asher, Saira. 2016. "The Moment Hijabs Dazzled the New York Fashion Week Catwalk." BBC News, September 16. Accessed June 28, 2017. http://www.bbc.com/news/world-asia37381770 .

Beauchemin, Chris, Christelle Hamel, and Patrick Simon, ed. 2016. Trajectoires et Origines. Enquête sur la Diversité des Populations en France. [Trajectories and Origins. Survey on Population Diversity in France]. Paris, France: INED Editions.

Berg, Linda, and Mikela Lundahl. 2016. "Un/veiling the West: Burkini-gate, Princess Hijab and Dressing as Struggle for Postsecular Integration." Culture Unbound 8 (3): 263-83.

Bhabha, Homi K. 1994. The Location of Culture. London, UK: Routledge.

Blanc, Florent, Sébastien Loisel, and Amandine Sherrer. 2005. "Politique étrangère et opinions publiques: les stratégies gouvernementales d'influence et de contrôle de l'opinion publique à l'épreuve de son internationalisation." ["Foreign Policies and Public Opinions: Governmental Strategies to Influence and Control Public Opinions Put to the Test by Globalization"] Raisons Politiques [Political Reasons] 19 (3): 119-41.

Boubekeur, Amel, 2005. "Cool and Competitive, Muslim Culture in the West." ISIM Review 16 (Autumn): 12-3.

Centre for the Analysis on Terrorism. 2017. European Jihad Watch: Issue 3; March 2017. http://cat-int.org/wp-content/uploads/2017/03/European-jihad-watch-mars-2017_eng. pdf.

Césari, Jocelyne. 1994. "De l'immigré au minoritaire: les Maghrébins de France." ["From Immigrants to Minority: North African People in France"]. Revue européenne des migrations internationales [European Review of International Migrations] 10 (1): 109-26.

2009. "The Securitisation of Islam in Europe." The Changing Landscape of European Liberty and Security. Research Paper No. 15 (April). https://www.ceps.eu/system/files/ book/1826.pdf.

2013. Why the West Fears Islam. New York, NY: Palgrave MacMillan.

Chaambi, Abdelaziz, Nadjib Achour, and Youssef Girard. 2012. "Le capital contre l'Islam (1/2)." ["Capitalism versus Islam"] Investig'Action. [Investigation and Action] Accessed March 10, 2017. http://www.michelcollon.info/Le-capital-contre-1-Islam-1-2.html.

Chemin, Anne. 2016. "Communautarisme la déchirure." ["Multiculturalism: The Fracture"]. Le Monde [The World], June 4. 
Dargent, Claude. 2003. "Les musulmans déclarés en France: affirmation religieuse, subordination sociale et progressisme politiques." ["Self-Declared Muslims in France: Religious Affirmation, Social Subordination and Political Progressivism"]. Les Cahiers $d u$ CEVIPOF [Workbooks of the Centre for the Study of French Political Life] 34 (February): $1-43$.

Dupont, Gaëlle, and Juliette Garnier. 2016. "Polémique sur la mode islamique." [Controversies over Islamic Fashion Le Monde [The World], April 3. Accessed June 28, 2017. http://www.lemonde.fr/societe/article/2016/04/02/polemique-sur-la-mode-islamique_ 4894454 3224.html.

European Monitoring Centre on Racism and Xenophobia (EUMC). 2006. Muslims in the European Union. Discrimination and Islamophobia. Accessed March 10, 2017. http://fra.europa.eu/ sites/default/files/fra_uploads/156-Manifestations_EN.pdf.

Europol. 2015. EU Terrorism Situation \& Trend Report. Accessed March 10, 2017. https://www.europol.europa.eu/activities-services/main-reports/european-unionterrorism-situation-and-trend-report-2015.

Friedman, Vanessa. 2014. "Reading the Subtleties of Islamic Fashion." The New York Times, November 25. https://www.nytimes.com/2014/11/27/fashion/reading-between-theseams-at-the-islamic-fashion-festival-in-malaysia.html.

2016. "From Breakthrough to Backlash." The New York Times, April 14.

Gallup. 2009. The Gallup Coexist Index 2009: A Global Study of Interfaith Relations. Accessed March 10, 2017. http://www.olir.it/areetematiche/pagine/documents/News_2150_ Gallup2009.pdf

Gauthier, François, and Tuomas Martikainen, dir. 2013. Religion in Consumer Society. Brands, Consumers and Markets. In Religion and Society Collection. Farnham: Ashgate.

2013. Religion in the Neoliberal Age. Political Economy and Modes of Governance. In Religion and Society Collection. Farnham: Ashgate.

Gaspard, Francois, and Farhad Khosrokhavar. 1995. Le foulard et la République. [The Veil and the Republic]. Paris, France: La Découverte.

Goodwin, Matthew, Tomas Raines, and David Cutts. 2017. "What Do Europeans Think about Muslim Immigration?" Chatham House, February 7. Accessed March 10, 2017. https://www.chathamhouse.org/expert/comment/what-do-europeans-think-aboutmuslim-immigration.

Guelph Mercury Tribune. 2010. "Muslim Streetwear Spreads across Europe with Trendy Designs, Tolerant Message." March 9. https://www.guelphmercury.com/news-story/2694475muslim-streetwear-spreads-across-europe-with-trendy-designs-tolerant-message/.

Hackett, Conrad. 2016. "5 Facts about the Muslim Population in Europe." Pew Research Centre, July 19. http://www.pewresearch.org/fact-tank/2016/07/19/5-facts-about-the-muslimpopulation-in-europe/.

Haenni, Patrick. 2008. "L'économie politique de la consommation musulmane." ["Political Economy of Muslim Consumption"]. Etudes et analyses [Studies and Analysis], November 18.

. 2011. "L'argent n'a pas d'odeur." ["Money has No Smell”]. Social Compass 58 (3): 316-22.

Hussain, Yasmine, and Paul Bagguley. 2005. "Citizenship, Ethnicity and Identity: British Pakistanis after the 2001 'Riots." Sociology 39 (3): 407-42.

Khaishgi, Amna Ehtesham. 2014. "Time for Islamic Couture." The National, November 24.

Klausen, Jytte. 2005. "Europe's Muslim Political Elite Walking a Tightrope." World Policy Journal 22 (3): 61-8.

Llana, Sara Miller. 2016. “As French Towns Ban the Burkini, Some Fashion Designers Embrace It.” The Christian Science Monitor, August 19. 
Laurence, Jonathan. 2012. "How to Integrate Europe's Muslims?" The New York Times, January 23.

, and Justin Vaïsse. 2006. Integrating Islam. Washington D.C.: Brookings Institution Press.

Lewis, Reina and Emma Tarlo. 2011. Modest Dressing. Faith-based Fashion and Internet Retail. Project Summary. London, UK: University of the Arts London, London College of Fashion.

Modood Tariq, Anna Triandafyllidou, and Ricard Zapata-Barrero, eds. 2006. Multiculturalism, Muslims and Citizenship. London/New York: Routledge.

Mogahed, Dalia. 2007. Beyond Multiculturalism vs Assimilation. The Gallup World Poll, Special Report: Muslims. Princeton: The Gallup Organization.

, and Rheault, Magali, 2008. "Common Ground for Europeans and Muslims among Them." Gallup, May 28. Accessed March 10, 2017. http://www.gallup.com/poll/107521/ Common-Ground-Europeans-Muslims-Among-Them.aspx

O'Brien, Peter. 2016. The Muslim Question in Europe, Political Controversies and Public Philosophies. Philadelphia, PA: Temple University Press.

Overmeyer, Laura. 2013. "Modern, Rebellious, and Pleasing in the Sight of God." Qantara.De. Accessed March 10, 2017. http://en.qantara.de/content/islamic-streetwear-from-thegerman-styleislam-label-modern-rebellious-and-pleasing-in-the.

Paton, Elizabeth. 2016. "A Muslim Fashion Identity." The New York Times, November 1. https://www.nytimes.com/2016/11/03/fashion/islamic-fashion-vogue-arabia.html.

Pew Global Attitudes Project. 2006. Few Signs of Backlash from Western Europeans. Muslims in Europe: Economic Worries Top Concerns About Religious and Cultural Identity. Washington D.C.: The Pew Research Center, July 6. Accessed March 10, 2017. http://pewglobal.org/files/pdf/7-6-06.pdf.

2008. Unfavorable Views of Jews and Muslims on the Increase in Europe, Washington D.C.: The Pew Research Center, September 17. Accessed March 10, 2017. http://pewglobal.org/files/pdf/262.pdf.

Prabu, Anjhali, 2005. Hybridity: Limits, Transformations, Prospects. New York, NY: SUNY Press.

Pras, Bernard, and Catherine Vaudour-Lagrace, 2007. "Marketing et Islam." ["Marketing and Islam"]. Revue française de gestion [French Review of Management] 171 (2): 195-223.

Samad, Yunas, and Katsuri Sen. 2007. Islam in the European Union Transnationalism, Youth and the War on Terror. Oxford: Oxford University Press.

Savage, Timothy M. 2004. "Europe and Islam: Crescent Waxing, Cultures Clashing." The Washington Quarterly 27 (3): 25-50.

Schain, Martin A. 2008. The Politics of Immigration in France, Britain, and the United States. New York, NY: Palgrave Macmillan.

Silvestri, Sara. 2007a. "Asserting Islam in the EU: Actors, Strategies and Priorities." In L'espace public européen à l'épreuve du religieux [European Public Space and the Challenge of Religion], edited by François Foret, 159-77. Bruxelles: Université Libre de Bruxelles.

2007b. "Muslim Institutions and Political Mobilisation" In European Islam: the Challenges for Public Policy and Society, edited by Samir Amghar, Amel Boubekeur, and Michael Emerson, 169-82. Brussels/Budapest: CEPS/OSI.

Swan, Melanie. 2015. "Islamic Fashion Design Course, a First for UAE." The National, September 17. http://www.thenational.ae/uae/islamic-fashion-design-course-a-first-foruae.

Tarlo, Emma. 2015. Visibly Muslim. Fashion, Politics, Faith. Oxford, UK: Bloomsberg Academic.

Thomson Reuters. 2015. State of the Global Islamic Economy 2014-2015 Report. http://www.iedcdubai.ae/assets/uploads/files/ar_20142015_1448266389.pdf.

Truong, Nicolas. 2016. "Entretien avec Elisabeth Badinter. Une partie de la gauche a baissé la garde." ["Interview with Elisabeth Badinter: A Part of the Left has Dropped Its Guard] Le Monde [The World], April 3. 
Valfort, Marie-Anne. 2015. Religious Discrimination in Access to Employment: A Reality. Institute Montaigne. Policy Paper, October. Accessed March 10, 2017. http://www.institutmontaigne.org/res/files/publications/discriminations-en.pdf.

Walker, Harriet. 2016. "Is your Hijab Ab Fab?” The Times, January 23.

Warner, Carolyn M., and Manfred W. Wenner. 2006. "Religion and the Political Organization of Muslims in Europe." Perspectives on Politics 4 (3): 457-79.

Werbner, Pnina. 2000. "Divided Loyalties, Empowered Citizenship? Muslims in Britain." Citizenship Studies 4 (3): 307-24.

\section{ABOUT THE AUTHOR}

Imene Ajala: Assistant Professor in International Studies, Arts and Humanities, University of Wollongong in Dubai, Dubai, United Arab Emirates. 


\section{The International Journal of Interdisciplinary}

Cultural Studies is one of seven thematically focused

journals in the family of journals that support the

Interdisciplinary Social Sciences knowledge community-

its journals, book series, conference, and online

community. The journal explores and exemplifies

disciplinary and interdisciplinary practices in the study

of human cultures and cultural interactions.

As well as papers of a traditional scholarly type, this journal invites case studies that take the form of presentations of practice-including documentation of socially-engaged practices and exegeses analyzing the effects of those practices.

The International Journal of Interdisciplinary Cultural Studies is a peer-reviewed scholarly journal. 